\title{
Are cariogenic bacteria the major risk factor to dental caries in patients with ulcerative colitis?
}

\author{
Eduardo RODRIGUES ${ }^{1}$, Nuno LARANJEIRA ${ }^{1}$, Gonçalo NUNES ${ }^{2}$, Lídia ROQUE-RAMOS ${ }^{2}$, \\ Ana VIEIRA ${ }^{2}$ and Jorge FONSECA ${ }^{1,2}$
}

Received 6/10/2018

Accepted 8/4/2019

\begin{abstract}
Background - High prevalence of dental caries in ulcerative colitis (UC) has been attributed to diet and changes in salivary environment. Objective - We aimed to characterize the prevalence of dental caries, salivary flow rates, salivary buffering capacity and cariogenic bacteria counts of Mutans streptococci and Lactobacillus spp and to evaluate their relationship with drug therapy, disease activity and duration. Methods - A cross-sectional study was performed with UC patients followed in a tertiary center. Participants were submitted to a questionnaire (including demographic data, oral hygiene, eating habits) and a clinical observation with assessment of plaque index and Decayed, Missing and Filled Teeth index. Unstimulated/ stimulated saliva was collected. Medical records, disease activity (Partial Mayo Score) and disease duration were collected. Laboratory data included salivary flow rates, salivary buffering capacity $\left(\mathrm{CRT}^{\circledR}\right.$ buffer) and cariogenic bacteria count (Mutans streptococci and Lactobacillus spp) in saliva using the CRT ${ }^{\circledR}$ bacteria test (results: high or low counts). Results - Thirty UC patients were recruited. Oral hygiene routines were daily teeth brushing once or more $(96.7 \%)$ and fluoride toothpaste $(73.3 \%)$. Decayed, Missing and Filled Teeth index (mean 16.17 \pm 6.428$)$ was not affected by the frequency of soft drinks, cakes, sweets and sugars between meals $(P>0.2)$. Long-term disease showed a trend towards higher prevalence of caries $(P=0.06)$. Most presented normal salivary flow rates, unstimulated $(73.3 \%)$ and stimulated $(60.0 \%)$, and high salivary buffering capacity $(66.7 \%)$. Any association was found with age, gender, disease activity, disease duration and drug therapy. High Mutans streptococci and low Lactobacillus spp count were observed in $73.3 \%$ and $60 \%$ of patients, respectively. Patients with active disease (100\%) and longer duration (88.9\%) displayed higher Mutans streptococci count. Conclusion - The prevalence of dental caries observed in UC patients was significant and did not seem to be influenced by their eating habits. The high prevalence of Mutans streptococci count may be a major risk factor for dental caries and may be looked as part of the UC dysbiosis. Dental care of UC patients should be planned according with this microbiota variation.
\end{abstract}

HEADINGS - Ulcerative colitis. Dental caries. Saliva. Streptococcus mutans. Lactobacillus.

\section{INTRODUCTION}

Ulcerative Colitis (UC) is one of the two main forms of chronic inflammatory bowel disease (IBD), the other being Crohn's disease $(\mathrm{CD})^{(1)}$. Typically, UC begins in the rectum and extends proximally in a contiguous pattern up to the entire colon ${ }^{(2-4)}$.

$\mathrm{UC}$ is a lifelong disease arising from the interaction between genetic and environmental factors but its pathogenesis is still unclear ${ }^{(3,5)}$. The most accepted hypothesis involves a disturbed immunological response to intestinal microbiota that leads to inflammation of the colonic mucosa in susceptible individuals ${ }^{(2,3)}$. Its evolution is characterized by periods of activity and remission of intestinal manifestations, which depends on the extent and severity of the inflammation ${ }^{(3,5)}$. Clinical manifestations typically include the presence of bloody diarrhea and abdominal pain. In fact, visible blood in the stool is the primary symptom in more than $90 \%$ of patients with active $\mathrm{UC}^{(4,5)}$.

Although the primary site of involvement is the bowel, the spectrum of UC includes a wide range of extraintestinal manifestations that may affect the skin, joints, eyes and liver ${ }^{(1,3,6)}$ and tend to follow the clinical course of bowel disease ${ }^{(3)}$.

A limited number of studies have reported the prevalence of oral signs and symptoms in patients with UC, including affections in the mucosa, periodontal tissue and teeth tissue. According to previous studies, UC seems to be associated with oral mucosa lesions and oral symptoms, especially in the active phase of the disease ${ }^{(7,89)}$, and to a higher risk of periodontitis ${ }^{(10-12)}$. Regarding dental caries, previous studies have reported a higher Decayed, Missing and Filled Teeth (DMFT) index in patients with UC compared to healthy control subjects ${ }^{(10,12,13)}$. The higher risk of dental caries has been attributed to poor dietary habits, malabsorption and changes in salivary and microbiological conditions of the oral cavity ${ }^{(10,13,14,15)}$. UC patients are said to present changes in the diet, increasing meal frequency and intake of carbohydrates, which may increase the risk of dental caries ${ }^{(14)}$. Also, it has been stated that, although CD patients have normal salivary flow rate and buffer capacity, the number of salivary cariogenic bacteria, Mutans streptococci (MS) and Lactobacillus spp. (LB), can be higher than the normal ${ }^{(15-17)}$. To the best of our knowledge, this was never evaluated in UC patients.

The aims of this study in UC patients were:

1. To characterize the dental caries, salivary flow rates and buffer capacity, and counts of cariogenic bacteria, MS and LB;

2. To evaluate the possible relationship between these features with age, gender, activity and duration of the disease and drug therapy. 


\section{METHODS}

A convenience sample of thirty adult patients who were previously diagnosed with UC was recruited for this study that was conducted at the General Gastroenterology and Inflammatory Bowel Disease Outpatient Clinic of a tertiary reference center of the Lisbon area, in Portugal.

The protocol used for data collection was previously reviewed and approved by the local ethics committee and all participants that accepted to join this study signed an informed consent.

Exclusion criteria were:

1. Patients under 18 years old;

2. Pregnant women;

3. Edentulous patients;

4. Patients with fixed orthodontic appliances;

5. Patients that underwent head and neck radiotherapy or colectomy;

6. Patients with other systemic diseases;

7. Patients that in the previous month were under drugs that could interfere with the variables evaluated such as antibiotics and anticholinergics.

The patient age was divided into three intervals to facilitate data treatment: $18-40$ years, 41 to 64 years and more than 64 years. Concerning smoking habits, the patients were grouped in non-smokers (including inactive past smokers) and active smokers (regardless of severity of the smoking habits).

Patient's medical records, disease activity and duration were evaluated by the gastroenterology team. Partial Mayo Score was used to define disease activity ${ }^{(18)}$. Scores of 2 or less without any subscore upper than 1 were considered as clinical remission ${ }^{(19)}$.

Patients were also classified according to UC drug therapy:

1. Non-medicated;

2. Salicylate therapy;

3. Corticosteroids therapy;

4. Treated with classic immunosuppressant drugs (azathioprine);

5. Under biological therapy (infliximab and adalimumab).

If any patient was medicated with more than one drug, the patient was included in the group that most influenced the evolution of UC. In increasing order: non-medicated, salicylates, corticosteroids, classic immunosuppressant drugs and biological therapy ${ }^{(7)}$.

Disease duration was divided into three intervals to facilitate data treatment: short term (up to 8 years), medium term ( 9 to 16 years) and long term (longer than 16 years).

\section{Clinical data}

All patients answered a standardized questionnaire, adapted from the World Health Organization (WHO) ${ }^{(20)}$ specifically for this study, that mostly included multiple-choice questions. The questionnaire included demographic data such as age, gender and smoking habits and questions concerning oral hygiene practice including frequency of teeth brushing, fluoridated paste, dental floss and mouthwashes. In addition, all patients were asked about eating habits, including consumption of fresh fruit, soft drinks, cakes, sweets and sugars between meals. The UC activity, clinical duration and drug therapy were also recorded.

\section{Clinical observation}

A mirror and a sterile disposable probe $\left(\right.$ Hygitech $\left.^{\circledR}\right)$ was used to measure oral hygiene level by the plaque index ${ }^{(21)}$ and the dental caries according to the DMFT index using the WHO criteria ${ }^{(20)}$. The diagnosis was based on clinical inspection without radiographs. Clinical observation was always performed by the same examiner in order to avoid protocol differences, preserving the concordance of the results.

\section{Collection and analysis of saliva}

Unstimulated saliva and stimulated saliva after chewing a paraffin wax from the $\mathrm{CRT}^{\circledR}$ buffer (CRT ${ }^{\circledR}$ buffer, Ivoclar Vivadent), were collected during five minutes for a specific bottle. To avoid contamination, the subjects were instructed not to eat, drink, smoke or brush their teeth two hours before sampling. Salivary flow rates were immediately calculated in milliliters per minute $(\mathrm{ml} / \mathrm{min})$ using sterile serological pipettes. The obtained values were categorized as normal, if higher than $0.25 \mathrm{~mL} / \mathrm{min}$ and $1.0 \mathrm{~mL} / \mathrm{min}$ for unstimulated and stimulated saliva respectively, or decreased (low and very low) if lower than these, according to the reference values described by Falcão et al. ${ }^{(22)}$. Afterwards, salivary buffering capacity was assessed as low, moderate or high through the colorimetric test CRT ${ }^{\circledR}$ buffer (CRT ${ }^{\circledR}$ buffer, Ivoclar Vivadent).

\section{Analysis of Mutans streptococci and Lactobacillus spp.}

$\mathrm{CRT}^{\circledR}$ bacteria (CRT ${ }^{\circledR}$ bacteria; Ivoclar Vivadent) was inoculated with stimulated saliva for salivary MS and LB culture according to the manufacturer instructions. The results were recorded as high counts if equal or greater than $10^{5}$ colony forming units (CFU)/ $\mathrm{mL}$ or low if lower than $10^{5} \mathrm{CFU} / \mathrm{mL}$.

\section{Statistical analysis}

The collected data was inserted in Microsoft Excel ${ }^{\mathrm{TM}}$ and SPSS $^{\mathrm{TM}}$ (Statistical Package for Social Sciences), 24.0 version, for statistical analysis. A descriptive analysis was initially performed to describe and summarize sample data. The Kolmogorov-Smirnov test was used to assess normality. T-test, ANOVA and chi-square were used to study the association between the different variables according with the study purpose. $P$-values of 0.05 or below were considered significant.

\section{RESULTS}

Thirty patients with UC were enrolled, 17 women and 13 men, with a mean age of $55.1 \pm 17.2$ years. Twenty-three $(76.7 \%)$ patients were non-smokers and seven $(23.3 \%)$ patients were active smokers. The mean UC clinical duration was $14.97 \pm 12.083$ years. Seven $(23.3 \%)$ patients presented active disease and $23(76.7 \%)$ patients were in remission. Most patients were medicated with salicylates $(n=13)$ and only two patients were receiving corticosteroids, the less frequently used therapy. The frequency of brushing twice or more times a day $(70.0 \%)$ and the use of fluoride toothpaste $(73.3 \%)$ were the most common oral hygiene measures (TABLE 1).

Among eating habits, fresh fruit consumption was referred as the most frequently eaten $(70.0 \%)$ whereas no patient reported frequent sugars between meals ingestion (FIGURE 1).

\section{Mean plaque and DMFT indexes}

Mean plaque index was $0.849 \pm 0.638$ and mean DMFT index was $16.17 \pm 6.428$. No significant differences were found between DMFT index and any other variable, with exception of smoking habits. DMFT index was superior in non-smokers $(P=0.01)$ al- 
TABLE 1. Clinical data of the UC patients for our sample $(n=30)$.

\begin{tabular}{|c|c|c|c|}
\hline & & $\mathrm{n}$ & $\%$ \\
\hline \multirow{10}{*}{ Demographic data } & Age & & \\
\hline & $18-40$ years & 8 & 26.7 \\
\hline & 41-64 years & 11 & 36.7 \\
\hline & $>64$ years & 11 & 36.7 \\
\hline & Gender & & \\
\hline & Male & 13 & 43.3 \\
\hline & Female & 17 & 56.7 \\
\hline & Smoking habits & & \\
\hline & Smokers & 7 & 23.3 \\
\hline & Non-smokers & 23 & 76.7 \\
\hline \multirow{13}{*}{$\begin{array}{l}\text { UC } \\
\text { characterization }\end{array}$} & Activity & & \\
\hline & Active disease & 7 & 23.3 \\
\hline & Clinical remission & 23 & 76.7 \\
\hline & Clinical duration & & \\
\hline & $0-8$ years (short term) & 12 & 40.0 \\
\hline & $9-16$ years (medium term) & 9 & 30.0 \\
\hline & $>16$ years (long term) & 9 & 30.0 \\
\hline & Drug therapy & & \\
\hline & Non-medicated & 4 & 13.3 \\
\hline & Salicylates & 13 & 43.3 \\
\hline & Corticosteroids & 2 & 6.7 \\
\hline & $\begin{array}{l}\text { Classic } \\
\text { immunosuppressants }\end{array}$ & 4 & 13.3 \\
\hline & Biological therapy & 7 & 23.3 \\
\hline
\end{tabular}

Frequency of tooth brushing

Twice to 6 times by week

Once a day

3.3

Twice or more times a day

$8 \quad 26.7$

Fluoridated paste

$\begin{array}{lcc}\text { Yes } & 22 & 73.3 \\ \text { No } & 3 & 10.0 \\ \text { Do not know } & 5 & 16.7\end{array}$

Oral hygiene practice

Dental floss

$\begin{array}{lll}\text { Yes } & 12 & 40 \\ \text { No } & 18 & 60\end{array}$

Mouthwashes

\begin{tabular}{lll} 
Yes & 15 & 50 \\
No & 15 & 50 \\
\hline
\end{tabular}

\begin{tabular}{|c|c|c|c|c|c|c|}
\hline \multirow[t]{2}{*}{ 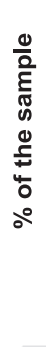 } & \multirow[t]{2}{*}{$\begin{array}{r}80.0 \% \\
70.0 \% \\
60.0 \% \\
50.0 \% \\
40.0 \% \\
30.0 \% \\
20.0 \% \\
10.0 \% \\
0.0 \%\end{array}$} & 田 & & & [ & \\
\hline & & $\begin{array}{l}\text { Fresh } \\
\text { fruit }\end{array}$ & $\begin{array}{c}\text { Soft } \\
\text { drinks }\end{array}$ & Cakes & Sweets & $\begin{array}{c}\text { Sugars } \\
\text { between } \\
\text { meals }\end{array}$ \\
\hline \multicolumn{2}{|c|}{ Never } & $0.0 \%$ & $40.0 \%$ & $6.7 \%$ & $16.7 \%$ & $16.7 \%$ \\
\hline \multicolumn{2}{|c|}{ Rarely } & $6.7 \%$ & $36.7 \%$ & $36.7 \%$ & $40.0 \%$ & $36.7 \%$ \\
\hline \multicolumn{2}{|c|}{ Sometimes } & $23.3 \%$ & $23.3 \%$ & $43.3 \%$ & $36.7 \%$ & $46.7 \%$ \\
\hline \multicolumn{2}{|c|}{ Often } & $70.0 \%$ & $0.0 \%$ & $13.3 \%$ & $6.7 \%$ & $0.0 \%$ \\
\hline
\end{tabular}

FIGURE 1. Eating habits frequency of UC patients.

though a higher mean age was observed in these patients $(P=0.025)$. Patients with longer disease had slightly higher DMFT values $(P=0.06)$, however patient mean age also increased with the UC clinical duration $(P=0.001)$ (TABLE 2$)$.

TABLE 2. Characterization of the mean age and DMFT index.

\begin{tabular}{lcccc}
\hline Characteristics & $\begin{array}{c}\text { Mean } \\
\text { age }\end{array}$ & $\boldsymbol{P}^{1}$ & $\begin{array}{c}\text { Mean DMFT } \\
\text { index }\end{array}$ & $\boldsymbol{P}^{2}$ \\
\hline Age & - & - & 12.6 & 0.15 \\
$18-40$ & - & & 16.1 & \\
$41-65$ & - & & 18.3 & \\
$>65$ & & & & \\
& & & 17.1 & 0.73 \\
Gender & 57.7 & 0.072 & 15.3 & \\
Male & 53.1 & & & \\
Female & & & & \\
& & & 13.5 & 0.01 \\
Smoking habits & 41.1 & 0.025 & 16.9 & \\
Smokers & 59.3 & & & \\
Non-smokers & & & & \\
& & & 13.1 & 0.65 \\
UC activity & 47.8 & 0.196 & 17.0 & \\
$\quad$ Active disease & 57.3 & &
\end{tabular}

UC duration

$\begin{array}{lllll}\text { Short term } & 42.7 & & 13.5 & \\ \text { Medium term } & 57.8 & 0.001 & 15.6 & 0.06 \\ \text { Long term } & 68.9 & & 20.1 & \end{array}$

UC drug therapy

$\begin{array}{lll}\text { Non-medicated } & 72.7 & 20.0\end{array}$

$\begin{array}{lll}\text { Salicylates } & 61.0 & 17.5\end{array}$

$\begin{array}{llll}\text { Corticosteroids } & 42.0 & 0.009 & 6.5\end{array}$

Classic $\quad 48.5 \quad 13.5$

immunosuppressants 48.5

Biological therapy $\quad 41.6 \quad 15.5$

$P^{1}$ indicates statistical significance of the difference between variables and mean age. $P^{2}$ indicates statistical significance between variables and mean DMFT index. 
Among eating habits and DMFT index (TABLE 3), this score only presented a statistical difference with fresh fruit consuming frequency $(P=0.03)$ and no statistical differences regarding soft drinks, cakes, sweets and sugars between meals.

TABLE 3. Eating habits frequency and mean DMFT.

\begin{tabular}{lccccc}
\hline $\begin{array}{l}\text { Eating } \\
\text { frequency }\end{array}$ & $\begin{array}{c}\text { Fresh } \\
\text { fruit }\end{array}$ & $\begin{array}{c}\text { Soft } \\
\text { drinks }\end{array}$ & Cakes & Sweets & $\begin{array}{c}\text { Sugars } \\
\text { between meals }\end{array}$ \\
\hline Never & - & 15.9 & 15.5 & 13.8 & 18.4 \\
Rarely & 15.5 & 17.9 & 16.2 & 15.7 & 17.8 \\
Sometimes & 10.7 & 13.7 & 17.0 & 18.4 & 14.0 \\
Often & 18.0 & - & 16.2 & 11.5 & - \\
$P$ & 0.03 & 0.418 & 0.93 & 0.389 & 0.245 \\
\hline
\end{tabular}

\section{Salivary flow rates and buffering capacity of saliva}

Most patients presented normal salivary flow rates, either of unstimulated saliva $(73.3 \%)$ or stimulated saliva $(60.0 \%)$. Salivary buffering capacity was high in $66.7 \%$ (TABLE 4 ). No differences were found among salivary flow rates and buffering capacity with age, gender, activity, clinical duration and UC drug therapy.

\section{Mutans streptococci and Lactobacillus spp. counts}

Regarding MS and LB counts (TABLE 4), most patients presented high MS $(73.3 \%)$ and low LB counts $(60.0 \%)$ with no significant differences according with age and gender groups. All patients with active disease and $65.2 \%$ of patients in remission presented high MS counts but this difference did not achieve statistical significance $(P=0.14)$. Concerning LB counts, the results were similar between patients in remission $(60.9 \%)$ and with active disease $(57.1 \%)(P=0.96)$. A higher MS count was observed $(88.9 \%)$ in patients with longer disease duration, also without significant differences $(P=0.58)$. The disease duration did not influence LB counts $(P=0.831)$. No statistical differences were found between MS and LB count with drug therapy ( $P=0.32$ and $P=0.41$, respectively).

\section{DISCUSSION}

To the best of our knowledge, this is the first study assessing the cariogenic bacteria and the salivary features of UC patients. In the present study, a mean DMFT index of 16.17 was found, which was superior to the mean value of the general Portuguese adult population $(9.0)^{(23)}$. Considering the approximation of the patient age intervals with those of the recent national study about the prevalence of oral diseases ${ }^{(24)}$, the prevalence of dental caries in UC patients is higher. The study performed by Brito and colleagues ${ }^{(10)}$, the first assessing carious lesions in UC patients, revealed a higher prevalence of caries in these patients compared to the control group, with significant statistical differences. Other previous studies also obtained similar outcomes that support our results ${ }^{(13,25)}$.

TABLE 4. Descriptive analysis between salivary flow rates, buffering capacity and bacteria counts with activity, duration and drug therapy of the UC (\%).

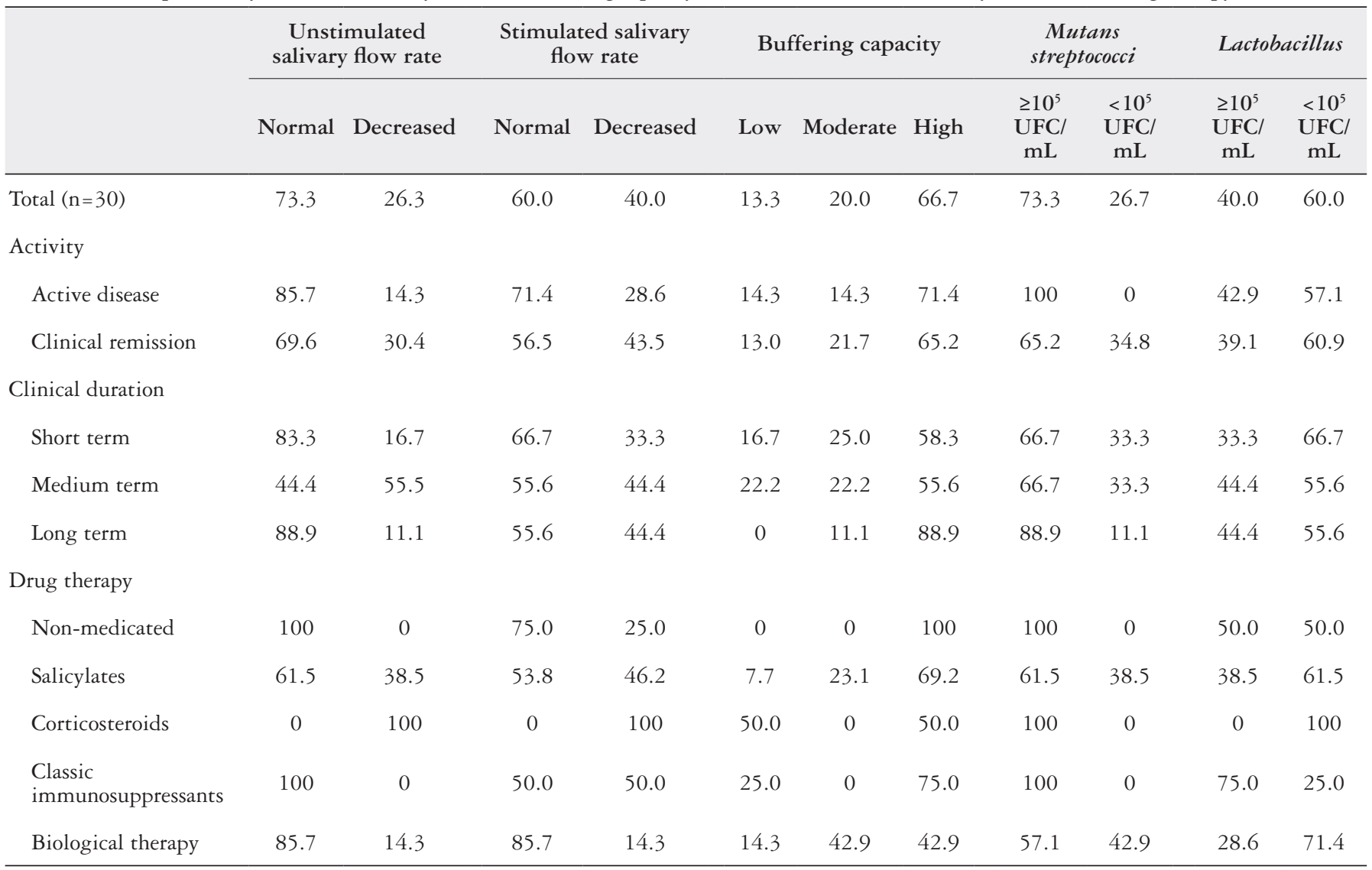


We registered a significant higher DMFT score in non-smokers patients that could be explained by the higher mean age and by the inclusion of ex-smokers in this group. However, we also verified a trend towards a worsening of the DMFT index with an increased in disease duration. Nevertheless, it should be noted that the mean age of this patient subgroup was also higher. The same trend was registered by Laranjeira et al. (2015) in UC patients ${ }^{(25)}$. In previous studies, the higher risk of dental caries has been mainly attributed to altered dietary habits, but salivary and microbiological changes were also suggested ${ }^{(10,13-15)}$.

Most of our patients presented normal salivary flow rates and no differences were found regarding UC activity, clinical duration and drug therapy. Previous studies in CD patients presented similar results and did not find significant differences in salivary rates with control group ${ }^{(16,17)}$ as well as between the salivary flow rates and the clinical activity of $\mathrm{CD}^{(16,26)}$.

Salivary buffering capacity was high in most patients, which could be a protective factor for dental caries, and no differences were found regarding UC activity, clinical duration and drug therapy. Some studies have already reported a high buffering capacity in CD patients. Previous studies have already reported a higher buffering capacity both in patients in remission and those with active disease that did not reach significant differences ${ }^{(26,27)}$.

Most patients in our sample presented high MS and low LB counts which is suggestive of a high risk to develop dental caries. Other previous studies also found higher counts of this cariogenic species in CD patients compared to control groups ${ }^{(16,17)}$. We also observed that all patients with active disease presented high MS counts, but there were no statistical differences when compared with patients in remission. This result is similar with a study in $C D$ patients that recorded a high MS count in patients with exacerbation of the disease when compared to remission, with statistical significance ${ }^{(27)}$. Nevertheless, in another study, in which highest cariogenic bacteria counts were observed in patients with $\mathrm{CD}$ without intestinal symptoms ${ }^{(16)}$. According to some authors, the high acidogenic bacterial count could be related to the dietary habits of patients in the active phase ${ }^{(28)}$. Patients with long-term disease display a higher MS count that did not reach statistical significance. Similar conclusions were already disclosed in a paper that identified a high number of cariogenic bacteria in the oral cavity in patients with a longer duration of $\mathrm{CD}^{(16)}$.

The frequency of eating habits of UC patients is resembling to the general portuguese population and dental caries index did not present significant difference regarding sugars between meals and simple sugars that are part of soft drinks, cakes and sweets ${ }^{(30)}$. The predominant oral hygiene habits were a frequency of brushing at least twice a day and fluoride paste use which are similar to the general Portuguese population data ${ }^{(29,30)}$. Sometimes, UC patients are said to present a dietary change, increasing intake of carbohydrates $^{(14)}$ which was not observed in our study. The plaque level is considered a small amount ${ }^{(31)}$. Also, in previous studies there was no difference regarding plaque between UC patients and control $\operatorname{group}^{(10,25)}$.

Although some protocol limitations have to be considered such as the use of a convenience sample with a reduced number of patients and the absence of a control group with healthy volunteers, our results demonstrate that the increased dental caries found in UC patients was not attributed to diet, decreased salivary flow neither buffering capacity. Caries seem to be largely due to increased cariogenic bacteria which is most evident in exacerbated or longer disease. This increase in cariogenic bacteria may be probably part of the known UC dysbiosis. Our results and the previous published data clearly point to the need of having a dentistry professional in the teams taking care of IBD patients.

\section{CONCLUSION}

In the present study, it appears to be a significant prevalence of dental caries in UC patients. The most of patients presented normal salivary flow rates, high buffering capacity, high MS and low LB counts. There were no differences regarding age, gender and UC activity, clinical duration and drug therapy. Eating habits of UC patients did not seem to influence the prevalence of dental caries. The high prevalence of MS count may be the major risk factor for dental caries in UC patients and may be looked as part of UC oral dysbiosis. Dental care of UC patients should be planned according with this oral microbiota variation. A dentistry professional should be included in the teams taking care of IBD patients.

\section{Ethical approval}

All procedures performed were in accordance with the ethical standards of the institutional and/or national research committee and with the 1964 Helsinki declaration and its later amendments or comparable ethical standards.

\section{Authors' contribution}

Rodrigues E performed literature search, data collection, analysis of the results and wrote the manuscript. Laranjeira $\mathrm{N}$ contributed to data collection and analysis. Nunes G, Roque-Ramos $\mathrm{L}$ and Vieira $\mathrm{A}$ also contribute to data collection and reviewed the text. Fonseca J conceived the structure of the study, supervised all its steps and reviewed the text. All authors approved the final version of the manuscript.

\section{Orcid}

Eduardo Rodrigues. Orcid: 0000-0002-0997-7622.

Nuno Laranjeira. Orcid: 0000-0003-4517-8956.

Gonçalo Nunes. Orcid: 0000-0003-4920-9158.

Lídia Roque-Ramos. Orcid: 0000-0002-7757-9490.

Ana Vieira. Orcid: 0000-0002-8503-4765.

Jorge Fonseca. Orcid: 0000-0001-6477-7028. 
Rodrigues E, Laranjeira N, Nunes G, Roque-Ramos L, Vieira A, Fonseca J. Serão as bactérias cariogénicas o fator de risco maior para cáries dentárias em doentes com retocolite ulcerativa? Arq Gastroenterol. 2019;56(2):118-23.

RESUMO - Contexto - Uma elevada prevalência de cáries dentárias em doentes com retocolite ulcerativa (RCU) tem sido atribuída à dieta e alterações no ambiente salivar. Objetivo - Este estudo pretende caracterizar a prevalência de cáries dentárias, taxas de fluxo salivar, capacidade de tamponamento da saliva e contagem de bactérias cariogénicas, Streptococcus mutans e Lactobacillus spp e avaliar a sua relação com a terapêutica farmacológica e a atividade e duração da doença. Métodos - Estudo transversal com doentes com RCU seguidos num centro terciário. Os participantes foram submetidos a um questionário (incluindo questões sobre dados sociodemográficos, higiene oral e hábitos alimentares), e a uma observação clínica com avaliação do índice de placa e índice Decayed, Missing and Filled Teeth. Amostras de saliva não estimulada e estimulada foram colhidas. Os registos clínicos, a atividade da doença (score parcial de Mayo) e a sua duração foram avaliados. Os dados laboratoriais incluíram taxas de fluxo salivar, capacidade de tamponamento da saliva (CRT ${ }^{\circledR}$ buffer) e a contagem de bactérias cariogénicas (Streptococcus mutans e Lactobacillus spp) utilizando o teste CRT ${ }^{\circledR}$ (resultado: contagem elevada ou reduzida). Resultados - Foram recrutados 30 doentes com RCU. As rotinas de higiene oral incluíram a escovagem

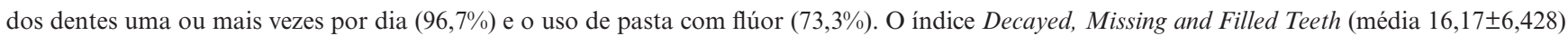
não foi afetado pela frequência de ingestão de refrigerantes, bolos, doces e açucares entre as refeições $(P>0,2)$. Doentes com doença de longa duração apresentaram uma tendência para maior prevalência de cáries dentárias $(P=0,06)$. A maioria possuía taxas de fluxo salivar normais, quer de saliva estimulada $(60 \%)$ quer de saliva não estimulada $(73,3 \%)$, assim como taxas de tamponamento salivar elevadas $(66,7 \%)$. Não foi encontrada associação entre estas características com a idade, género, atividade/duração da doença e tipo de terapêutica farmacológica. Contagens elevadas de Streptococcus mutans e reduzidas de Lactobacillus spp foram observadas em 73,3\% e 60\% dos doentes, respectivamente. Doentes com doença ativa e maior tempo de evolução apresentaram contagens superiores de Streptococcus mutans. Conclusão - A prevalência de cárie dentária observada em doentes com RCU foi significativa e não parece ser influenciada pelos hábitos alimentares. A prevalência aumentada de Streptococcus mutans foi o fator de risco maior para a cárie dentária e provavelmente constitui parte da conhecida disbiose oral associada à RCU. Os cuidados dentários a estes doentes deverão ter em consideração esta variação da microbiota.

DESCRITORES - Colite ulcerativa. Cárie dentária. Saliva. Streptococcus mutans. Lactobacillus.

\section{REFERENCES}

1. Feuerstein JD, Cheifetz AS. Ulcerative colitis: epidemiology, diagnosis, and management. Mayo Clin Proc. 2014;89:1553-63.

2. Ordás I, Eckmann L, Talamini M, Baumgart DC, Sandborn WJ. Ulcerative colitis. Lancet. 2012;380:1606-9.

3. Tan CXW, Brand HS, de Boer NKH, Forouzanfar T. Gastrointestinal diseases and their oro-dental manifestations: part 2: ulcerative colitis. Br Dent J. 2017;222:53-7.

4. Conrad K, Roggenbuck D, Laass MW. Diagnosis and classification of ulcerative colitis. Autoimmun Rev. 2014;13:463-6.

5. Magro F, Gionchetti P, Eliakim R, Ardizzone S, Armuzzi A, Barreiro-de Acosta $\mathrm{M}$, et al. Third European evidence-based consensus on the diagnosis and management of ulcerative colitis part 1: definitions, diagnosis, extra-intestinal manifestations, pregnancy, cancer surveillance, surgery, and ileo-anal pouch disorders. J Crohns Colitis. 2017:1-39.

6. Fatahzadeh M. Inflammatory bowel disease. Oral Surg Oral Med Oral Pathol Oral Radiol Endod. 2009;108:1-10.

7. Laranjeira N, Fonseca J, Meira T, Freitas J, Valido S, Leitão J. Oral mucosa lesions and oral symptoms in inflammatory bowel disease patients. Arq Gastroenterol. 2015;52:105-10.

8. Katz J, Shenkman A, Stavropoulos F, Melzer E. Oral signs and symptoms in relation to disease activity and site of involvement in patients with inflammatory bowel disease. Oral Diseases. 2003:9:34-40.

9. Elahi M, Telkabadi M, Samadi V, Vakili H. Association of oral manifestations with ulcerative colitis. Gastroenterol Hepatol Bed Bench. 2012;5:155-60.

10. Brito F, de Barros FC, Zaltman C, Carvalho AT, Carneiro AJ, Fischer RG, et al. Prevalence of periodontitis and DMFT index in patients with crohn's disease and ulcerative colitis. J Clin Periodontol. 2008;35:555-60.

11. Laranjeira N, Coutinho R, Freitas J, Fonseca J, Leitão J. Periodontal evaluation in patients diagnosed with inflammatory bowel disease. Int Poster J Dent Oral Med. 2015, poster 974. [Internet]. Available from: http://hdl.handle.net/10400.26/18468

12. Papageorgiou SN, Hagner M, Nogueira AVB, Franke A, Jäger A, Deschner J. Inflammatory bowel disease and oral health: systematic review and a meta-analysis. J Clin Periodontol. 2017;44:382-93.

13. Francis DL. Oral health status of ulcerative colitis patients: a comparative study. Inflammatory Bowel Diseases. 2016;22:S24

14. Johannsen A, Fored MC, Håkansson J, Ekbom A, Gustafsson A. Consumption of dental treatment in patients with inflammatory bowel disease, a register study. PLoS One. 2015;10:e0134001.

15. Grössner-Schreiber B, Fetter T, Hedderich J, Kocher T, Schreiber S, Jepsen S Prevalence of dental caries and periodontal disease in patients with inflammatory bowel disease: a case-control study. J Clin Periodontol. 2006;33:478-84.

16. Sundh B, Johansson I, Emilson CG, Nordgren S, Birkhed D. Salivary antimicrobial proteins in patients with Crohn's disease. Oral Surg Oral Med Oral Pathol. 1993; 76:564-9.
17. Szymanska S, Lördal M, Rathnayake N, Gustafsson A, Johannsen A. Dental caries, prevalence and risk factors in patients with Crohn's disease. PLoS One. 2014;9:e91059.

18. Lewis JD, Chuai S, Nessel L, Lichtenstein GR, Aberra FN, Ellenberg JH. Use of the non-invasive components of the mayo score to assess clinical response in ulcerative colitis. Inflamm Bowel Dis. 2008;14:1660-6.

19. Magro F, Benito-Garcia E, Cremers I, Correia L, Cotter J, Duarte MA, et al. Terapêutica de manutenção da remissão na colite ulcerosa moderada a grave. Jornal Português de Gastrenterologia. 2011; 18: 170-8. Available from: http:// www.scielo.mec.pt/pdf/ge/v18n4/v18n4a04.pdf

20. World Health Organization. (2013). Oral Health Surveys: Basic Methods, 5th edition. Geneva, Switzerland: WHO. Available from: http://www.who.int/ oral_health/publications/9789241548649/en/

21. Silness J, Löe H. Periodontal disease in pregnancy II. Correlation between oral hygiene and periodontal condition. Acta Odontol Scand. 1964;22:121-35.

22. Falcão DP, da Mota LMH, Pires AL, Bezerra ACB. Sialometria: aspectos de interesse clínico. Rev Bras Reumatolo. 2013;53:525-31.

23. Colgate e SPEMD. (December, 2012). Mês da saúde oral da Colgate e SPEMD. Available from: http://www.spemd.pt/imagens/anexo_613.pdf

24. Calado R, Ferreira CS, Nogueira P, Melo P. III Estudo Nacional de Prevalência das Doenças Orais (2015). Available from: https://www.dgs.pt/documentos-e-publicacoes/iii-estudo-nacional-de-prevalencia-das-doencas-orais.aspx

25. Laranjeira N. Manifestações orais da doença inflamatória intestinal (Tese de Doutoramento). Universidade Católica Portuguesa, Portugal, 2015.

26. Halme L, Meurman JH, Laine P von Smitten K, Syrjänen S, Lindqvist C, Strand-Pettinen I. Oral findings in patients with active or inactive Crohn's disease. Oral Surg Oral Med Oral Pathol. 1993;76:175-81.

27. Meurman JK, Halme L, Laine P, von Smitten K, Lindqvist C. Gingival and dental status, salivary acidogenic bacteria, and yeast counts of patients with active or inactive Crohn's disease. Oral Surg Oral Med Oral Pathol. 1994;77:465-8.

28. Koutsochristou V, Zellos A, Dimakou K, Panayotou I, Siahanidou S, Roma-Giannikou, Tsami A. Dental caries and periodontal disease in children and adolescents with inflammatory bowel disease: a case-control study. Inflamm Bowel Dis. 2015;21:1839-46.

29. Melo P, Marques S, Silva OM. Portuguese self-reported oral-hygiene habits and oral status. Int Dent J. 2017;67:139-47.

30. Eurobarómetro sobre saúde oral. (2010). Available from: http://ec.europa.eu/ commfrontoffice/publicopinion/archives/ebs/ebs_330_en.pdf

31. Feier I, Onisei D, Onisei D. The plurivalence of the interpretation of correlation between plaque score and bleeding score. Journal of Romanian Medical Dentistry. 2009;13:45-8. Available from: http://www.ijmd.ro/articole/43_8.pdf 